\title{
A Bíblia na relação entre Teologia e Literatura: Volumes I e II
}

Alex Villas Boas

Antonio Manzatto

Editores Teoliteraria

Porque que tudo que invento já foi dito nos dois livros que eu li: as escrituras de Deus, as escrituras de João. Tudo é Bíblias. Tudo é Grande Sertão.

Adélia Prado, A invenção de um modo

que a poeta mineira Adélia Prado descreve poeticamente acima vem ao encontro do que já dizia Albertino Mussato (1261-1329 dC), em carta ao dominicano Giovannino de Mantua, ao apresentar nove razões para reconhecer a poesia [em sentido latu] como divina, a saber: 1) desde suas primeiras manifestações a poesia era chamada de divina; 2 ) a poesia trata de questões teológicas; 3) poetas são chamados de profetas; 4) a poesia nos foi dada por Deus; 5 ) a poesia nos causa maravilhas e deleites ao ouvi-la; 6) Moisés usou poesia 
para agradecer a Deus pela libertação de Israel da escravidão; 7) a poesia está em consonância com a Bíblia; 8) a beleza da poesia é eterna, e 9) a fé cristã foi anunciada através da poesia. Por tais motivos, os antigos poetas, como a Bíblia mesmo, foram inspirados diretamente por Deus.

Assim, do mesmo modo que Moisés é o criador da theologia poetica, Virgílio é redescoberto como poeta theologus, visto, portanto, como portador de palavras de salvação para Dante na Divina comédia. Também um téologo judeu medieval chamado Moisés Ibn Ezra, no século XI, usava a poética de Aristóteles para provar que a Bíblia era uma obra literária

Com efeito, a relação entre literatura e teologia não se inicia na era moderna, pois já Alonso Schökel, em seus Estudos de Poética Hebrea entende que no período chamado patrístico do Cristianismo há uma atenção à questão da literatura por parte da teologia, sobretudo a partir do Edito de Juliano em 362dc em que proibia o acesso aos clássicos profanos no cristianismo imperial, desenvolvendo-se assim uma "autêntica qualidade literária formativa".

O que passa a ocorrer no período contemporâneo é que, por um lado, essa relação é revisitada no século XX, resultando em uma redescoberta do sentido literário da Bíblia, fonte teológica por excelência, dentro de um panorama científico, ou seja, à luz da ciência da linguagem, e por outro, fonte de inspiração poética não só para a fé ou os temas tradicionalmente ligados a ela, mas também como fonte de inspiração para questões essencialmente humanas. Deste modo a relação entre Bíblia e Literatura é complexa e com inúmeros desdobramentos, a começar do fato de que a Bíblia enquanto literatura indica que a lógica poética se constitui como primeira forma de fazer teologia.

Sendo assim, como tentativa de aprofundar o diálogo entre Teologia e Literatura a Bíblia se constitui como objeto de preocupação no ano de 2014, por parte da ALALITE Internacional. Os inúmeros trabalhos que se seguem nesta edição e na seguinte, repercutem, sobretudo, o esforço de grupos de pesquisa em aproximar a literatura da Bíblia como forma 
de diálogo com teologia, seja para extrair sua poética própria, para encontrar as fontes de inspiração de autores clássicos, modernos e contemporâneos, seja para ampliar a percepção de novos modos de pensar teologicamente a questão Deus.

De modo especial, queremos aqui fazer menção a alguns grandes blocos que encamparam tal tarefa, a saber: o SIPLET (Seminário Interdisciplinario Permantente de Literatura, Estética y Teología) da Universidad Católica de Argentina (UCA) liderado por Cecília Avenatti Palumbo, atual presidenta da ALALITE Internacional (2015-2016), que se dedicou a pensar a relação entre literatura bíblica com a reflexão teológica, a partir de Paul Ricoeur, nos últimos anos; o Seminário de Literatura y Fé ligado à Pontifícia Universidad de Católica Chile, coordenado por Clemens Franken, até então presidente da ALALITE Internacional que organizou o $V^{\circ}$ Coloquio Latinoamericano de Literatura y Teologia, tendo por tema Bíblia y Literatura; e por fim, cabe a menção aos pesquisadores brasileiros, em especial o Grupo de Pesquisa LERTE (Literatura, Religião e Teologia) da Pontifícia Universidade Católica de São Paulo (PUC-SP), e ao grupo de pesquisadores da Faculdade Jesuíta de Filosofia e Teologia (FAJE), que integraram as discussões sobre Bíblia e Literatura neste ano. Algumas outras contribuições de demais autores também estão contempladas nesta edição e naquela que se seguirá: Bíblia na relação entre Teologia e Literatura Vol. I e II.

$\mathrm{Na}$ tentativa de estabelecer uma epistemologia do diálogo entre Teologia e Literatura na ALALITE , a Literatura Bíblica foi e é certamente, um ponto de convergência para entender as escrituras de Deus ou meIhor dizendo as bíblias "sagradas" de poetas profanos e as bíblias "profanas" dos poetas sagrados, porém, como diria Adélia: "Tudo é Bíblias".

Cabe aqui ainda dizer dos novos rumos da Teoliterária - Revista Brasileira de Teologias e Literaturas, que acaba de firmar vínculos com a Associação Latino Americana de Literatura e Teologia [ALALITE] e o Programa de Estudos Pós-Graduados em Teologia da Pontifícia 
Universidade Católica de São Paulo, que incorpora o periódico em suas atividades, passando a ser a responsável por sua edição; membros de ALALITE internacional integram distintas comissões deste periódico, o que o faz constituir-se como um canal privilegiado de difusão, produção acadêmica e aprofundamento da questão do diálogo entre Teologia e Literatura. 